Arch Virol (2000) 145: 1857-1866

\begin{tabular}{c} 
Archives of \\
Virology \\
$\substack{\text { @ Springer-verlag } 2000 \\
\text { Prineted in Austria }}$ \\
\hline
\end{tabular}

\title{
The nucleotide sequence of Indian peanut clump virus RNA 2: sequence comparisons among pecluviruses
}

\author{
R. A. Naidu ${ }^{1, *}$, J. S. Miller ${ }^{2}$, M. A. Mayo $^{2}$, S. V. Wesley ${ }^{2, * *}$, and A. S. Reddy ${ }^{1}$ \\ ${ }^{1}$ International Crops Research Institute for the Semi-Arid Tropics (ICRISAT), \\ Patancheru (PO), Andhra Pradesh, India \\ ${ }^{2}$ Scottish Crop Research Institute, Invergowrie, Dundee, U.K.
}

Accepted March 15, 2000

\begin{abstract}
Summary. The RNA-2 molecule of an isolate of the L serotype of Indian peanut clump virus (IPCV) was shown to consist of 4290 nucleotides with five open reading frames (ORF). The arrangement of the ORFs resembled that in RNA-2 of Peanut clump virus (PCV) from West Africa. The proteins encoded by the ORFs in IPCV-L RNA are between $32 \%$ and $93 \%$ identical to those encoded by PCV RNA. Partial sequence data for the RNA-2 of isolates of the $\mathrm{H}$ and $\mathrm{T}$ serotypes of IPCV show that the coat and P40 proteins encoded by the $5^{\prime}$-most ORFs of RNA-2 of IPCV-L, IPCV-H and IPCV-T are as similar to each other as any is to the corresponding proteins of PCV. A conserved motif ' $\mathrm{F}-\mathrm{E}-\mathrm{x}_{6}-\mathrm{W}$ ' is present near the C-termini of the coat proteins of all three IPCV serotypes and of PCV, as it is in the coat proteins of other viruses that have rod-shaped particles, such as Tobacco mosaic virus and Tobacco rattle virus. The results support the distinction of IPCV and PCV as separate virus species, but also raise the question of how the serotypes of IPCV should be classified.
\end{abstract}

\section{Introduction}

Peanut clump is a soil-borne disease of the groundnut (peanut; Arachis hypogaea L.) crop. In West Africa, the causal agent is Peanut clump virus (PCV; [27]) and in India, it is Indian peanut clump virus (IPCV; [22]). Both viruses are transmitted by the motile zoospores of Polymyxa graminis, and can persist in contaminated soil for long periods. Peanut clump disease can have serious economic impacts in

*Present address: Department of Plant Pathology, University of Georgia, Athens, GA 30602-7274, U.S.A.

**Present address: Division of Plant Industry, CSIRO, Canberra, Australia. 
certain regions of India and Africa [24]. Particles of PCV and IPCV are rod-shaped with two predominant lengths, and contain RNAs of c. $6 \mathrm{~kb}$ (RNA-1) or c. $4.5 \mathrm{~kb}$ (RNA-2) that comprise the bipartite genome. IPCV and PCV were previously classified in the genus Furovirus, along with all other viruses with rod-shaped particles that have fungus vectors [2]. However, a recent re-classification of these viruses along the lines advocated by Torrance and Mayo [28] has placed them as the two species that constitute the genus Pecluvirus [5, 14].

Several isolates of IPCV have been collected from various groundnut-growing areas in India. Based on serology, they were separated into three distinct serotypes, Hyderabad (H), Ludhiana (L) or Thalod (T) [21]. These serotypes are found in geographically separated areas of India [21], although isolates of the T serotype have been found at several locations [21]. The results of nucleic acid hybridization tests in solution suggested $50 \%$ to $60 \%$ apparent nucleotide sequence homology among isolates of IPCV-H, IPCV-L, and IPCV-B, which belong, respectively, to the $\mathrm{H}, \mathrm{L}$, and T serotypes. IPCV-H and IPCV-B seemed to be more closely related to each other than either was to IPCV-L [23]. Tests with an isolate of PCV gave estimates of $29 \%$ to $41 \%$ homology.

The nucleotide sequence of the genome of one isolate of PCV has shown that it encodes seven polypetides, two in RNA-1 and five in RNA-2 [9, 12]. The coat proteins of pecluviruses are encoded by RNA-2. The coat proteins of PCV and of IPCV-H are 61\% identical in sequence [29], whereas RNA-1s of PCV and IPCV-H are c. $80 \%$ identical in sequence [19]. The work described in this paper was done to assess the extent of sequence variation among the serotypes of IPCV. Sequences were determined for all of RNA-2 of IPCV-L, for substantial fragments of RNA-2 of IPCV-D, an isolate belonging to the T serotype, and for a further portion of the $\mathrm{H}$ serotype isolate studied previously [29]. Comparisons among the sequences have provided details both for comparisons between the two pecluvirus species (PCV and IPCV) and for comparisons among the serotypes of IPCV. The results suggest that some revision of pecluvirus taxonomy may be necessary. A preliminary report has been published [20].

\section{Materials and methods}

\section{Purification of virus and extraction of viral RNA}

The Ludhiana (Punjab State) and Durgapura (Rajasthan State) isolates, belonging respectively to the $\mathrm{L}$ and $\mathrm{T}$ serotypes, were propagated separately in Phaseolus vulgaris $\mathrm{cv}$. Local, and particles were purified as described by Reddy et al. [23]. The Hyderabad (Andhra Pradesh State) isolate (H serotype) was propagated, and its particles were purified, as described previously [29]. RNA was extracted from purified virus particles as described by Mayo and Reddy [15]. RNA 2 was separated from RNA 1 by electrophoresis in low-melting-point agarose gels, eluted and recovered by precipitation from $70 \%$ ethanol.

\section{Cloning and sequencing of RNA 2}

The RNA was denatured at $65^{\circ} \mathrm{C}$ for $5 \mathrm{~min}$, annealed with random composition hexadeoxynucleotides and used as a template for cDNA synthesis [8]. The resulting ds cDNA was blunt-ended with T4 DNA polymerase, ligated into the phagemid vector pUC119 at the Sma 
I site, and transformed into $E$. coli $\mathrm{DH} 5 \propto$. Colonies thought to contain recombinant plasmids were assessed for the presence of RNA 2-specific sequences by examining minipreparation plasmid DNA [25] by restriction enzyme analysis and Southern hybridization using ${ }^{32} \mathrm{P}$-labelled, randomly primed, cDNA of RNA 2 as a probe.

The cDNA inserts from these clones were subcloned into M13 mp18 or mp19 dsDNA and nucleotide sequences of the corresponding ssDNA were determined by using the dideoxy chain termination method [26] with the Sequenase Version II Kit (United States Biochemical). Based on the sequence information generated, oligonucleotide primers, corresponding to IPCV-L RNA-2 nucleotides 555-576 (sense) and 2090-2107 (complementary), and 31063126 (sense) and 3639-3659 (complementary), were designed to amplify regions of RNA 2 that were not represented in the cDNA clones, using reverse transcription and the polymerase chain reaction (RT-PCR). The PCR products were directly cloned into M13 vectors after digestion at appropriate restriction enzyme sites for nucleotide sequence determination as described above. The $3^{\prime}$ and $5^{\prime}$ ends of the RNA 2 were amplified using the $5^{\prime}$-Amplifinder ${ }^{\mathrm{TM}}$ Race Kit (Clontech) and the PCR products were cloned directly into pGEM-T (Promega). The oligonucleotides used were complementary to the sequence between either nucleotides 128 and 147 or nucleotides 450 and 469 (for cloning the $5^{\prime}$ end), or identical to the sequence between nucleotides 3630 and 3651 (for cloning the $3^{\prime}$ end) of IPCV-L RNA-2. The resulting double-stranded DNA was used for sequence analysis. All the sequences were determined in both DNA orientations.

\section{Sequence analysis}

The nucleotide sequences were assembled as described in [16] and compared by using programs in the GCG package [4] and CLUSTALV [10].

The nucleotide sequences of RNA described in this paper are deposited under accession numbers AF239729 (IPCV-L), AF239730 (IPCV-H), and AF239731 and AF239732 (IPCV-D).

\section{Results}

\section{Nucleotide sequence of IPCV-L RNA-2}

The IPCV-L RNA-2 is 4290 nucleotides in length and contains 5 open reading frames (ORF) in 2 regions of contiguous or overlapping sequence (Fig. 1). The non-coding regions consist of $388\left(5^{\prime}\right), 84$ (between coding regions) and $280\left(3^{\prime}\right)$ nucleotides. The arrangement of the ORFs is closely similar to that in RNA-2 of PCV $[9,12]$. The non-coding regions are also like those of PCV in size except

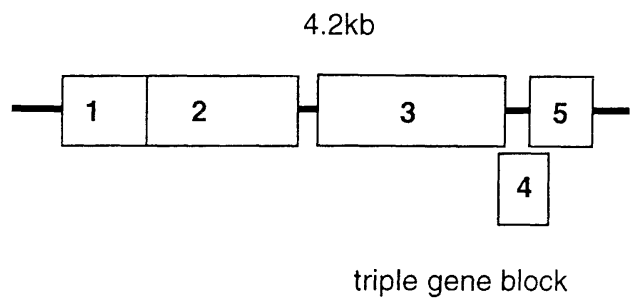

Fig. 1. The arrangement of open reading frames (ORF) in RNA 2 of IPCV. The RNA is represented by a solid line, ORFs are represented by open boxes. The boxes indicate only the positions of the ORFs, not their reading frames. ORF1 and ORF2 are in different frames in RNA of IPCV-H and IPCV-L 
that the central region in PCV RNA-2 is longer (136 nucleotides) than that in IPCV-L RNA-2 (84 nucleotides). The central non-coding region contains little other than repeats of the type $\mathrm{GU}_{\mathrm{n}}$, where $\mathrm{n}$ is 1 to 6 , and these sequences are also present in PCV RNA-2. The $3^{\prime}$ non-coding regions of RNA-1 and RNA-2 components of IPCV were all about $91 \%$ identical; those of PCV were about $95 \%$ identical. The $5^{\prime}$ (5'-GUAUUC-) and 3' (-UCCCA-3') terminal sequences are the same in RNA-2 molecules of IPCV-L, IPCV-H [29] and PCV [12], and in RNA-1 molecules of IPCV-H [19] and PCV [9]. A conserved sequence of 20 nucleotides (5'-UACCAUCCCUUGUAUCCAAA) is present in RNA-2 molecules of all three IPCV serotypes and PCV about 50 nucleotides downstream of the $5^{\prime}$-end. Also, like RNA-1 of PCV and IPCV-H, but unlike PCV RNA-2 [6, 9], IPCV-L RNA-2 can be folded to form a tRNA-like structure that contains an anticodon for valine. The few substitutions in the sequence of IPCV-L RNA-2 from those folded by Goodwin and Dreher [6] did not noticeably weaken the folded structure proposed by them.

\section{Partial sequences of RNA-2 of IPCV-H and IPCV-D}

In contrast to work with RNA-2 of IPCV-L, repeated attempts to clone cDNA representing the entirety of RNA- 2 of either IPCV-H or IPCV-D were unsuccessful. For IPCV-H, cDNA comprising 894 nucleotides (i.e. representing most of ORF-2) was obtained, which together with the sequence published earlier [29] amounts to about $2 \mathrm{~kb}$ of the molecule. For IPCV-D, cDNA was obtained that could be assembled into two contiguous pieces. The first comprised $1143 \mathrm{nu}$ cleotides that appeared to consist of 224 nucleotides of $5^{\prime}$-non-coding sequence, ORF 1 and 256 nucleotides of ORF 2. The second piece consisted of 404 nucleotides of ORF 2, an intergenic non-coding region of 207 nucleotides and 1270 nucleotides that corresponded to most of ORF 3 . The sequences of the encoded proteins were used, along with IPCV-L sequences, to make comparisons with sequences of $\mathrm{PCV}$ and other viruses.

\section{RNA-2-encoded proteins}

ORF 1 of pecluvirus RNA-2 encodes the coat protein. However, the termination codons of these viruses differ; they are UGA for IPCV-L and PCV, but UAA for IPCV-H and IPCV-D. As with PCV RNA-2 [12], the termination codon of ORF 1 is very close to the initiation codon of ORF 2 . However, the details of how the ORFs overlap differ. The ORFs in PCV RNA overlap as a -4 frameshift [12] but those in IPCV-H and IPCV-L RNAs overlap as a -1 frameshift and the ORFs in IPCV-D RNA are contiguous (Fig. 2).

The polypeptide encoded by IPCV-L ORF 2 is 354 amino acids in length (P40). ORFs 3, 4 and 5 overlap and encode a "triple gene block" of proteins that comprise 409 amino acids (46 K), 120 amino acids (14 K) and 154 amino acids $(17 \mathrm{~K})$. The corresponding non-structural proteins of PCV comprise 367 amino acids (P39), 446 amino acids (P51), 122 amino acids (P14) and 153 amino acids (P17) $[9,12]$. 


\begin{tabular}{|c|c|c|}
\hline IPCV-L & $O R F 1 \quad C C U \cup G A \cup G$ & ORF 2 \\
\hline IPCV-H & $O R F 1$ A A U UA & ORF 2 \\
\hline IPCV-D & $O R F 1 A A \cup U A A A \cup G$ & ORF 2 \\
\hline PCV & ORF 1 C A UGAGC & ORF 2 \\
\hline
\end{tabular}

Fig. 2. Nucleotide sequences at the $3^{\prime}$ ends of ORF 1 and the $5^{\prime}$ ends of ORF 2 of IPCV strains and of PCV. ORFs 1 and 2 are indicated as boxed regions

Table 1. Percentage identity between polypeptides encoded by the five open reading frames (ORF) of IPCV-L and the corresponding ORFs of other viruses

\begin{tabular}{lllllll}
\hline & ORF 1 (coat) & $\begin{array}{l}\text { ORF 2 } \\
(1-97)\end{array}$ & $\begin{array}{l}\text { ORF 2 } \\
(245-\text {-end })\end{array}$ & ORF 3 & ORF 4 & ORF 5 \\
\hline IPCV-H & $65 \%$ & $44 \%$ & $16 \%^{\mathrm{a}}$ & - & - & - \\
IPCV-D & $63 \%$ & $36 \%$ & $17 \%^{\mathrm{a}}$ & $86 \%$ & - & - \\
PCV & $67 \%$ & $44 \%^{\mathrm{b}}$ & $8 \%^{\mathrm{a}, \mathrm{b}}$ & $80 \%$ & $93 \%$ & $65 \%$ \\
BSMV & $33 \%$ & - & - & $38 \%$ & $55 \%$ & $32 \%$ \\
PMTV & $19 \%^{\mathrm{a}}$ & - & - & $40 \%$ & $56 \%$ & $32 \%$ \\
BNYVV & $17 \%^{\mathrm{a}}$ & - & - & $29 \%$ & $32 \%$ & $22 \%$
\end{tabular}

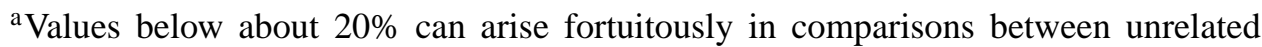
polypeptide sequences

${ }^{b}$ The entire sequence is $32 \%$ identical to that of ORF 2-encoded protein of IPCV-L

\section{Sequence comparisons among IPCV serotypes and PCV}

Table 1 shows the percentage identities calculated during multiple sequence alignments of the different polypeptides encoded by the ORFs of IPCV-L RNA-2 with corresponding proteins encoded by RNA-2 of IPCV-H, IPCV-D, PCV and Potato mop-top virus (PMTV), Barley stripe mosaic virus (BSMV) and Beet necrotic yellow vein virus (BNYVV). It was previously shown that the coat proteins of IPCV-H and of PCV resembled the coat protein of BSMV more than that of any other virus coat protein tested [29]. PMTV and BNYVV were previously classified as members of the same genus as IPCV and PCV, but recently proposed taxonomic changes [28], subsequently adopted by ICTV [5, 14], have classified these viruses in separate, unlinked genera.

Figure 3 shows an alignment of the coat protein sequences of IPCV-L, -H and $-\mathrm{D}$ and of PCV. There are several conserved domains with the most notable conservation being between residues 65 and 74, and between residues 112 and 122. However, the striking differences (Fig. 3) are at the C-terminus. Here the coat protein sequences differ in length and amino acid composition, especially in sequences downstream of the conserved tryptophan residue at position 193 (indicated by the arrow in Fig. 3). 


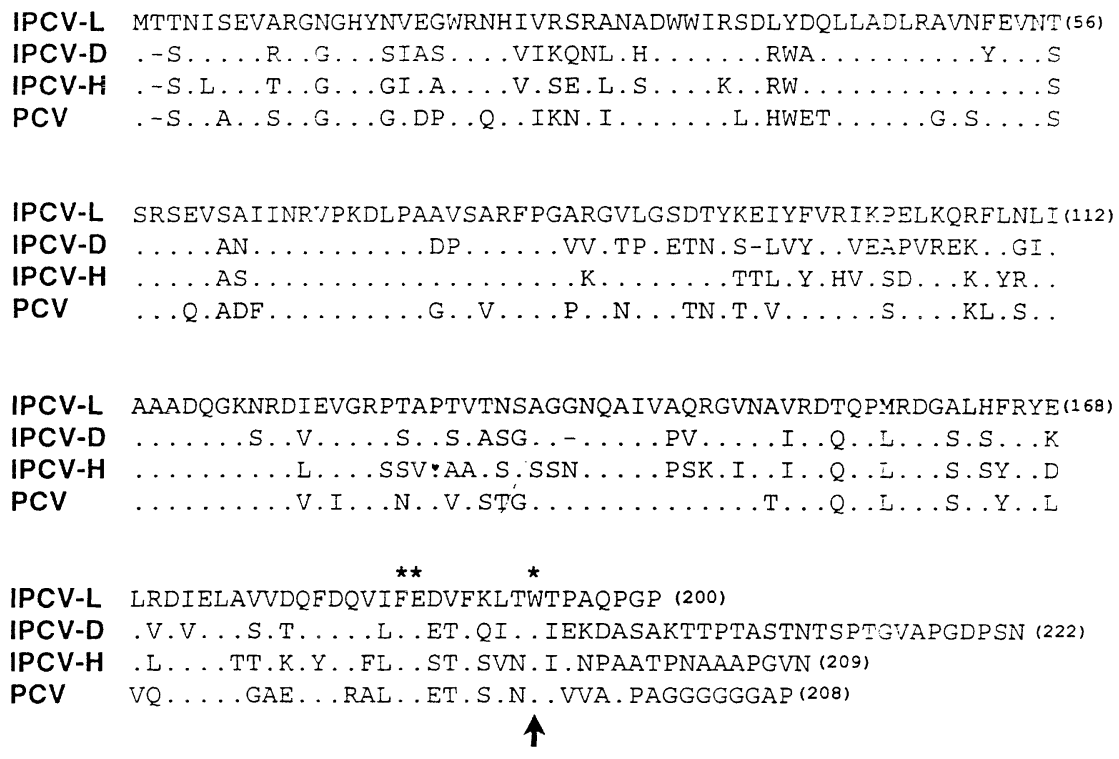

Fig. 3. Alignments comparing the coat protein of IPCV-L with those of IPCV-D, IPCV-H and PCV. Amino acids identical to those in the IPCV-L sequence are shown as dots, a dash indicates the absence of a corresponding amino acid. The asterisks and the arrow indicate respectively the conserved $\mathrm{F}-\mathrm{Ex}_{6}-\mathrm{W}$ sequence and the tryptophan $(\mathrm{W})$ residues mentioned in the text

The ORF 2 translation product does not have an analogue in the genomes of other viruses, and no proteins were detected in BLAST searches of databases using the sequences of IPCV-L P40. Because the sequence of P40 of IPCV-D was available only in 2 pieces, comparisons were made with each, that is the $\mathrm{N}$-terminal 97 amino acids and the C-terminal c. 130 amino acids. The results (Table 1) differed markedly depending on the piece compared. The C-terminal portions were not significantly similar ( $<20 \%$ identity) among IPCV-L, IPCV-H and PCV or between IPCV-D and either IPCV-L or PCV. However, IPCV-H and IPCV-D sequences were $48 \%$ identical in this region. In contrast, the N-terminal regions of $\mathrm{P} 40$ were $36 \%$ to $44 \%$ identical depending on the viruses compared, and IPCV-H and IPCV-D sequences were not noticeably more alike than were corresponding sequences of the other viruses. In the sequence alignments of the $\mathrm{N}$-terminal portions, the amino acid triplets ' $\mathrm{G}-\mathrm{H}-\mathrm{I}$ ' and ' $\mathrm{G}-\mathrm{C}-\mathrm{P}$ ' were present in all the sequences. All the $\mathrm{P} 40$ analogues are rich in leucine residues and that of IPCV-L contains the motif ' $\mathrm{L}-\mathrm{x}_{6}-\mathrm{L}-\mathrm{x}_{6}-\mathrm{L}-\mathrm{x}_{6}-\mathrm{L}$ ' (in which $\mathrm{x}$ signifies any amino acid) that is characteristic of a "leucine zipper" [11]. The significance of these features is unclear. Possibly, one or more are involved in interaction with the fungus vector.

Among pecluviruses, the ORF 3 and ORF 4 translation products were more closely alike than were any other of the encoded proteins; the ORF 4 product was the most alike, although the only comparison possible was between proteins of IPCV-L and PCV. The ORF 5 translation product of IPCV-L was $65 \%$ identical 
to that of PCV and $32 \%$ identical to those of the corresponding TGBs of BSMV and PMTV, although unlike the coat protein of BSMV, that of PMTV was not significantly similar to that of IPCV-L. The TGB proteins of BNYVV were only distantly related to those of IPCV-L (Table 1). In alignments of the protein encoded by ORF 3 of IPCV-L RNA-2 and the analogous proteins of other viruses, there was a marked discontinuity in the degree of similarity among $\mathrm{N}$-terminal and among C-terminal portions. Whereas in the C-terminal 328 amino acids, 283 $(86 \%)$ residues were identical in IPCV-L, IPCV-D and PCV, in the remaining $\mathrm{N}$-terminal portions of the proteins, no amino acid residues could be aligned in all three sequences.

\section{Discussion}

The arrangements of the genes, both in RNA-1 and RNA-2 of IPCV, resemble those of genes in PCV RNAs. This is consistent with the earlier classification of these viruses as strains of one species, peanut clump virus, in the genus Furovirus [2]. However, these viruses are now classifed in a new genus, Pecluvirus, as species Peanut clump virus and species Indian peanut clump virus [5]. This classification reflects their similar and distinctive genome organizations, and dissimilarities in sequence characteristic of different species within a genus. The present results extend the range of sequence comparisons published so far to cover all of the genome of at least one isolate of each species. Whereas some proteins differ appreciably between the species (in particular P40 analogues), those of the triple gene block, and those encoded by RNA-1 [19] do not differ greatly.

The amino acid sequences of coat proteins of viruses that have rigid rodshaped particles share some sequence features with the coat proteins of IPCV and PCV. In particular, a motif ' $\mathrm{F}-\mathrm{E}-\mathrm{x}_{6}-\mathrm{W}$ ' is present near the C-termini of the coat proteins of these viruses (asterisks in Fig. 3). These residues are thought to play key structural roles in the formation of the virus particles [1]. In the coat proteins of Tobacco mosaic virus and Tobacco rattle virus (TRV), amino acids to the C-terminal side of the conserved tryptophan are located to the outside of the virus particle $[1,7]$. The analogous sequences in pecluvirus coat proteins are therefore probably also to the outside of the virus particle. Also, whereas IPCV and PCV coat proteins are similar in sequence and length upstream of the conserved tryptophan residue, the downstream sequences differ markedly among serotypes of IPCV. This supports the idea that these regions do not play a role in forming the rod-shaped structure of pecluvirus particles. However the amino acid compositions of these C-terminal structures were very similar among the pecluviruses, being noticeably rich in G,P,A,S and T (Fig. 3). The amino acid compositions of the corresponding regions of tobravirus coat proteins are also particularly rich in the amino acids A,N,G,T,S and P [17]. The C-terminal region of the coat protein of Pepper ringspot virus has been shown by NMR to be mobile in virus particles $[3,17]$ and it was proposed that these terminal structures play a role in the transmission of tobravirus particles by nematodes [17]. It is not known how the zoospores of the fungus $P$. graminis transmit PCV or IPCV, or even if the 
transmission involves the virus particles disassembling in the fungus structures. But the long C-terminal structure discovered in the coat protein of IPCV-D, and its presumed exposure on the surface of the particles of this virus, raise the possibility that the mechanics of pecluvirus transmission by $P$. graminis may be similar to those of tobravirus transmission by nematodes.

The results described here do little to support the current taxonomy of the genus Pecluvirus [5]. The separation of PCV and IPCV into different species is based mainly on the origins of the species (Africa or India). Although there are serological differences between isolates of the two species, there are similar differences among isolates from within each species $[13,21]$. The results of the sequence comparisons also do little to reinforce the division of the genus along largely geographical lines. The viruses from India diverge as much, or nearly as much, from each other as they do individually from PCV. A more rational classification of these viruses might therefore be into several species, perhaps based largely on the coat protein and P40 sequences. The alternative of clustering all the viruses into a single species would not be useful, as that would displace the need for discrimination down a taxonomic level but do nothing to resolve it. However, a decision on these ideas must probably await knowledge of the extent of sequence differences among proteins of isolates of PCV known to be serologically distinct [13].

\section{Acknowledgements}

R. A. Naidu is grateful to the Underwood Fund administered by the Biotechnology and Biological Sciences Research Council, UK, for financial assistance to carry out part of this research. J. S. Miller was funded by the UK Overseas Development Administration (currently the Department for International Development) (project R5417) and M. A. Mayo was supported by the Scottish Office Agriculture, Environment and Fisheries Department (currently the Scottish Executive Rural Affairs Department).

\section{References}

1. Altschuh D, Lesk AM, Bloomer AC, Klug A (1987) Correlation of co-ordinated amino acid substitutions with function in viruses related to tobacco mosaic virus. J Mol Biol 193: 693-707

2. Brunt AA (1995) Genus Furovirus. In: Murphy FA, Fauquet CM, Bishop DHL, Ghabrial SA, Jarvis AW, Martelli GP, Mayo MA, Summers MD (eds) Virus Taxonomy. Classification and Nomenclature of Viruses. Sixth Report of the International Committee on Taxonomy of Viruses. Springer, Wien New York, pp 445-449 (Arch Virol [Suppl] 10)

3. Brierley KM, Goodman BA, Mayo MA (1993) A mobile element on a virus particle surface identified by nuclear magnetic resonance spectroscopy. Biochem J 293: $657-659$

4. Devereux J, Haeberli P, Smithies O (1984) A comprehensive set of sequence analysis programs for the VAX. Nucleic Acids Res 12: 387-395

5. Fritsch C, Dollet M (2000) Genus Pecluvirus. In: Van Regenmortel MHV, Fauquet CM, Bishop DHL, Carstens E, Estes M, Lemon S, Maniloff J, Mayo MA, McGeoch D, Pringle CR, Wickner RB (eds) Virus Taxonomy. Seventh Report of the International Committee on Taxonomy of Viruses. Academic Press, San Diego, New York (in press) 
6. Goodwin JB, Dreher TW (1998) Transfer RNA mimicry in a new group of positivestrand RNA plant viruses, the furoviruses: differential aminoacylation between the RNA components of one genome. Virology 246: 170-178

7. Goulden MG, Davies JW, Wood KR, Lomonossoff GP (1992) Structure of tobraviral particles: model suggested from sequence conservation in tobraviral and tobamoviral coat proteins. J Mol Biol 227: 1-8

8. Gubler U, Hoffman BJ (1983) A simple and very efficient method for generating cDNA libraries. J Mol Biol 227: 1-8

9. Herzog E, Guilley H, Manohar SK, Dollet M, Richards K, Fritsch C, Jonard G (1994) Complete nucleotide sequence of peanut clump virus RNA 1 and relationships with other fungus-transmitted rod-shaped viruses. J Gen Virol 75: 3 147-3 155

10. Higgins DG, Bleasby AJ, Fuchs R (1992) CLUSTALV: improved software for multiple sequence alignment. CABIOS 8: 189-191

11. Landschulz WH, Johnson PF, McKnight SL (1988) The leucine zipper: A new hypothetical structure common to a new class of DNA binding proteins. Science 240: 1759-1 764

12. Manohar SK, Guilley H, Dollet M, Richards K, Jonard G (1993) Nucleotide sequence and genetic organization of peanut clump virus RNA 2 and partial characterization of deleted forms. Virology 195: 33-41

13. Manohar SK, Dollet M, Dubern J, Gargani D (1995) Studies on variability of peanut clump virus: symptomatology and serology. J Phytopathol 143: 233-238

14. Mayo MA (1999) Developments in plant virus taxonomy since the publication of the $6^{\text {th }}$ ICTV Report. Arch Virol 144: 1659-1 666

15. Mayo MA, Reddy DVR (1985) Translation products of RNA from Indian peanut clump virus. J Gen Virol 66: 1347-1 351

16. Mayo MA, Robinson DJ, Jolly CA, Hyman L (1989) Nucleotide sequence of potato leafroll luteovirus RNA. J. Gen Virol 70: 1037-1051

17. Mayo MA, Brierley KM, Goodman BA (1993) Developments in the understanding of the particle structure of tobraviruses. Biochimie 75: 639-644

18. Mayo MA, Robertson WM, Legorboru FJ, Brierley KM (1994) Molecular approaches to an understanding of the transmission of plant viruses by nematodes. In: Lamberti $\mathrm{F}$, De Giorgi C, Bird D McK (eds) Advances in molecular nematology. Plenum Press, New York and London, pp 277-293

19. Miller JS, Wesley SV, Naidu RA, Reddy DVR, Mayo MA (1996) The nucleotide sequence of RNA-1 of Indian peanut clump furovirus. Arch Virol 141: 2301-2 312

20. Naidu RA, Miller JS, Mayo MA, Reddy AS (1996) The nucleotide sequence of Indian peanut clump virus RNA 2. Proceedings of the Third International Working Group on Plant Viruses with Fungal Vectors, Dundee. American Society of Sugar Beet Technologists, pp 77-80

21. Nolt BL, Rajeshwari R, Reddy DVR, Bharatan N, Manohar SK (1988) Indian peanut clump virus isolates: host range, symptomatology, serological relationships, and some physical properties. Phytopathology 78: 310-313

22. Reddy DVR, Rajeshwari R, Iizuka N, Lesemann DE, Nolt BL, Goto T (1983) The occurrence of Indian peanut clump, a soil-borne virus disease of groundnuts (Arachis hypogaea) in India. Ann Appl Biol 102: 305-310

23. Reddy DVR, Robinson DJ, Roberts IM, Harrison BD (1985) Genome properties and relationships of Indian peanut clump virus. J Gen Virol 66: 2011-2 016

24. Reddy DVR, Delfosse P, Mayo MA (1999) Pecluviruses. In: Webster R, Granoff A (eds) Encyclopedia of virology. Academic Press, San Diego, pp 1 196-1 200

25. Sambrook J, Fritsch EF, Maniatis T (1989) Molecular cloning: A laboratory manual, 2nd ed. Cold Spring Harbor Laboratory Press, Cold Spring Harbor 
26. Sanger F, Nicklen S, Coulson AR (1977) DNA sequencing with chain-terminating inhibitors. Proc Natl Acad Sci USA 74: 5463-5 467

27. Thouvenal JC, Fauquet C (1981) Further properties of peanut clump virus and studies on its natural transmission. Ann Appl Biol 97: 99-107

28. Torrance L, Mayo MA (1997) Proposed re-classification of furoviruses. Arch Virol 142: 435-439

29. Wesley SV, Mayo MA, Jolly CA, Naidu RA, Reddy DVR, Jana MK, Parnaik VK (1994) The coat protein of Indian peanut clump virus: relationships with other furoviruses and with barley stripe mosaic virus. Arch Virol 134: 271-278

Authors' address: Dr. R. A. Naidu, Department of Plant Pathology, University of Georgia, Athens, GA 30602-7274, U.S.A.

Received December 17, 1999 